\title{
PERSEPSI MASYARAKAT AKAN BANK SYARIAH YANG ADA DI INDONESIA Menggunakan Teknik One Sample $T$ test dan Independent Sample $T$ Test
}

\author{
Muhammad Yuda Tri Wiratama \\ (yudatriwiratama@yahoo.com)
}

\begin{abstract}
Perkembangan lembaga- lembaga keuangan islam tegolong cepat, dan salah satu alasannya ialah karena adanya keyakinan kuat di kalangan masyarakat muslim bahwa perbangkan konvensional itu mengandung unsur riba yang dilarang oleh agama Islam. Pada makalah ini pendekatan yang digunakan yaitu melalui pendekatan kuantitatif dengan analisis Rasch untuk mengukur kepentingan relatif dari dua atribut bank syariah kepada masyarakat, dengan teknik pengujian One Sample t test dan Independent Sample $t$ test. Hasil pengolahan data kuisioner dari jumlah lima belas responden menunjukan bahwa dengan menggunakan teknik One sample $t$ test diperoleh kesimpulan rata-rata uang yang ditabung di bank pada setiap bulan oleh mahasiswa maupun mahasiswi tidak sama dengan asumsi / dugaan yang sudah ditentukan sebelumnya yaitu sebesar $\mathrm{Rp}$ 1.000.000. Pada persepsi "Bank syariah memiliki sistem bagi hasil yang lebih menguntungkan bagi nasabah" diperoleh hasil bahwa tidak terdapat perbedaan persepsi antara mahasiswa dengan mahasiswi mengenai Bank syariah memiliki sistem bagi hasil yang lebih menguntungakan bagi nasabah.
\end{abstract}

Kata kunci: Perbankan syariah, Persepsi masyarakat, Analisis Rasch, Uji Beda 


\section{Pendahuluan}

Perkembangan ekonomi islam atau lembaga keuangan islam di Indonesia dapat dikatakan cukup pesat, hal tersebut dapat dilihat dari cukup banyaknya kajian-kajian yang sudah dipublikasikan mengenai prinsip dan praktek bank syariah. Menurut Arifin (2009), Perkembangan lembagalembaga keuangan islam tegolong cepat, dan salah satu alasannya ialah karena adanya keyakinan kuat di kalangan masyarakat muslim bahwa perbangkan konvensional itu mengandung unsur riba yang dilarang oleh agama Islam.

Di Indonesia, praktek perbankan syariah bermula pada tahun 1992, yang ditandai dengan beroperasinya Bank Muamalat Indonesia (BMI) dan merupakan bank pertama yang menerapkan sistem bagi hasil. Pembentukan BMI ini diikuti oleh pendirian bank-bank perkreditan rakyat syariah (BPRS). Namun karena lembaga tersebut masih dirasakan kurang mencukupi dan belum sanggup menjangkau masyarakat Islam pada lapisan bawah, maka dibangunlah lembaga-lembaga simpan pinjam yang disebut Bait al Maal wat Tamwil (BMT), (Arifin, 2009).

Fenomena bank syariah di Indonesia memberikan pemahaman pada umat Islam Indonesia adanya kelembagaan ekonomi dalam perspektif Islam. Berdirinya bank syariah merupakan salah satu usaha untuk menerapkan prinsip syariah Islam secara bertahap dengan maksud mengatasi kelemahan umat saat ini dalam bidang ekonomi dan kesejahteraannya. Keberadaan bank syariah diharapkan mampu mewujudkan sitem perbankan yang lebih kompetitif, efisien, dan memenuhi prinsip kehati-hatian serta diharapkan mampu mendukung sector riil melalui kegiatan pembiayaan yang bebasis bagi hasil dan berdasarkan dari unsur riba untuk mewujudkan keadilan dalam kegiatan ekonomi,dan mencapai kemaslahatan masyarakat (Heniffa:2008).

\section{Landasan Teori}

Menurut Kasmir (2014), Bank adalah badan usaha yang menghimpun dana dari masyarakat dalam bentuk simpanan dan menyalurkannya kembali kepada masyarakat dalam bentuk kredit dan atau bentuk-bentuk lainnya dalam rangka meningkatkan taraf hidup rakyat banyak.

Bank syariah adalah lembaga keuangan yang bertugas menghimpun dana dari masyarakat, menyalurkan dana kepada masyarakat, dan memberi jasa keuangan kepada masyarakat dengan menggunakan kaidah atau aturan yang berlaku di ajaran agama Islam. Pelaksanaan kegiatan yang dijalankan bank syariah dalam penentuan harga dinilai berdasarkan kesepakatan antara pihak bank dengan pihak nasabah atau penyimpan dana sesuai pilihan jenis produk simpanan yang dimiliki bank tersebut dan jangka waktu yang nantinya akan menentukan besar kecil porsi bagi hasil yang akan diterima nasabah atau penyimpan dana. Sebutan bagi hasil merupakan keuntungan yang diterima nasabah dalam penyimpanan dana nya pada bank syariah. Berdasarkan Undang-undang No. 20 Tahun 2008 tentang perbankan syariah, mendefinisikan bank syariah adalah bank yang menjalankan usahanya berdasarkan prinsip syariah, yaitu dengan prinsip - prinsip yang diambil atau 
yang ditafsirkan dari Al-Qur'an dan Hadits sebagai sumber hukum Islam itu sendiri. Sedangkan Bank konvensional adalah lembaga keuangan yang menjalankan suatu kegiatan usaha dengan cara menyediakan jasa dengan ruang lingkup pembayaran secara umum dan didasarkan sesuai prosedur serta ketentuan yang sudah ditetapkan sebelumnya oleh sistem perbankan. Pada situs http://www.definisi-pengertian.com/2015/07/definisi-pengertianbank-konvensional-syariah.htm/ menulis pendapat dari Martono (2002) pada buku yang berjudul "Bank dan Lembaga Keuangan Lain" menjelaskan bahwa terdapat dua metode prinsip yang digunakan bank konvensional yakni penetapan bunga sebagai harga, baik untuk produk simpanan seperti tabungan, deposito berjangka, maupun produk pinjaman (kredit) yang diberikan berdasarkan tingkat bunga tertentu, serta jasa bank lainnya yang digunakan bank konvensional penerapan biaya financial dalam presentase atau nominal tertentu yang disebut fee based.

Berdasarkan penjelasan singkat teori di atas, maka perbedaan hal yang paling umum dalam operasional bank terletak pada penetapan harga kegiatan simpan pinjam antara pihak bank maupun nasabah atau penyimpan dana dari masing-masing produk yang dipilih. Bank konvensional menetapkan harga yang telah ditentukan baik secara nominal maupun persentase bunga, sedangkan bank syariah menetapkan harga pelaksanaan kegiatan operasionalnya berdasarkan kesepakatan kedua belah pihak dalam menjalankan amanat nasabah atau penyimpan dana yang disebut bagi hasil.

\section{Metode}

Pada makalah ini pendekatan yang digunakan yaitu melalui pendekatan kuantitatif dengan analisis Rasch untuk mengukur kepentingan relatif dari dua atribut bank syariah kepada masyarakat, dengan teknik pengujian One Sample $t$ test dan Independent Sample $t$ test. Pengmpulan data dilakukan dengan menggunakan kuisioner yang disebarkan secara langsung kepada responden yang berjumlah lima belas (15) orang yang merupakan mahasiswa di perguruan tinggi swasta di kota Bogor. Kuisioner dibagi kedalam dua pernyataan pilihan yaitu mengenai jenis kelamin responden, dan rata-rata uang yang ditabung setiap bulan yang terdiri dari beberapa pilihan ganda yang sudah ditentukan, sebagai berikut (A) Rp 1.000.000, (B) Rp 1.500.000, dan (C) Rp 2.000.000. Kemudian dua buah pernyataan yang akan digunakan sebagai persepi yang diuji, yaitu (A) Bank syariah memiliki sistem bagi hasil yang lebih menguntungkan bagi nasabah, serta (B) Bank syariah memiliki fasilitas ATM yang memadai. Kedua pernyataan tersebut kemudian diisi dengan acuan menggunakan skala $1-7$, dimana skor 1 (satu) menyatakan sangat tidak setuju, dan sampai dengan skor 7 (tujuh) menyatakan sangat setuju.

Responden merupakan mahasiswa dan mahasiswi pada perguruan tinggi swasta di kota Bogor, yang pernah menggunakan atau bertransaksi di bank syariah sebagai nasabah maupun bukan sebagai nasabah di bank tersebut. Jumlah responden yang digunakan sebanyak lima belas (15) orang terdiri dari delapan (8) orang mahasiswi, dan tujuh (7) orang mahasiswa. 
Menurut Setiawan (2015) teknik 1-sample t-test pada SPSS dilakukan melalui fitur Analyze - Compare Mean. Dijelaskan oleh Setiawan (2013), nilai mean (rata-rata) merupakan salah satu bagian dari analisis ukuran pemusatan data. Teknik t-test adalah sebagai teknik pengujian hipotesis deskriptif yang memiliki tiga kriteria yaitu uji pihak kanan, kiri, dan kedua pihak. Teknik independent t-test pada SPSS dilakukan melalui fitur Analyze Compare Mean. Teknik independent t-test salah satu uji parametik untuk melakukan komparasi independen seperti contoh hal nya adalah perbandingan antara laki-laki dan perempan yang akan di bahas pada penelitian ini. Kedua teknik yang digunakan mengikuti panduan dari e-book yang di tulis pada blog Budi Setiawan berjudul "Teknik Praktis Analisis Data Penelitian Sosial dan Bisnis dengan SPSS.

\section{Hasil}

\subsection{Gambaran Singkat Karakteristik Responden}

Responden yang digunakan berjumlah lima belas orang dimana delapan orang berjenis kelamis perempuan dan tujuh orang berjanis kelamin laki-laki, seluruh responden merupakan mahasiswa dan mahasiswi di perguruan tinggi swasta di kota Bogor yang pernah menggunakan atau bertransaksi di bank syariah sebagai nasabah maupun bukan sebagai nasabah di bank tersebut. Berikut merupakan data responden yang akan digunakan untuk pengujian perespi mengenai bank syariah, ditujukan pada Tabel 1.

Tabel 1 Data Responden

\begin{tabular}{|c|c|c|c|c|c|}
\hline \multirow{2}{*}{ NO } & \multirow{2}{*}{ RESPONDEN } & \multirow{2}{*}{ JENIS KELAMIN } & \multirow{2}{*}{$\begin{array}{l}\text { TABUNGAN } \\
\text { (Rp. Juta) }\end{array}$} & \multicolumn{2}{|c|}{ PERSEPSI } \\
\hline & & & & $\mathbf{A}$ & B \\
\hline 1 & Anna & $P$ & 1,0 & 5 & 4 \\
\hline 2 & Yuli & $P$ & 1,5 & 5 & 3 \\
\hline 3 & Dinda & $P$ & 1,0 & 6 & 3 \\
\hline 4 & Fira & $P$ & 1,0 & 4 & 4 \\
\hline 5 & Nesa & $P$ & 2,0 & 5 & 5 \\
\hline 6 & Nida & $P$ & 1,5 & 6 & 4 \\
\hline 7 & Keisha & $P$ & 1,5 & 5 & 2 \\
\hline 8 & Sinta & $P$ & 1,0 & 6 & 3 \\
\hline 9 & Yusuf & $\mathrm{L}$ & 2,0 & 4 & 3 \\
\hline 10 & Sapta & L & 1,5 & 5 & 5 \\
\hline 11 & Rizki & L & 2,0 & 5 & 4 \\
\hline 12 & Agung & L & 1,0 & 4 & 3 \\
\hline 13 & Diki & L & 1,5 & 3 & 3 \\
\hline 14 & Okky & L & 1,5 & 5 & 2 \\
\hline 15 & Indra & L & 2,0 & 4 & 3 \\
\hline
\end{tabular}

Sumber : Data diolah, 2018

Data tersebut kemudian akan digunakan sebagai input untuk melakukan analisis persepsi masyarakat akan bank syariah, dalam hal ini adalah mahasiswa dan mahasiswi. Analisis diakukan dengan menggunakan dua 
jenis teknik yaitu teknik One Sample $t$ test dan Independent Sample $t$ test. Berikut merupakan dugaan dan persepsi yang digunakan dalam analisis :

1. Teknik One Sample t test

Dugaan yang digunakan pada teknik ini adalah Rata-rata uang yang ditabung di bank pada setiap bulan (X). Pada teknik ini hasil yang ingin diperoleh yaitu apakah terdapat perbedaan rata-rata uang yang ditabung oleh responden setiap bulannya. Dengan asumsi dugaan adalah rata-rata uang yang ditabung sebesar Rp 1.000.000,-

2. Teknik Independent Sample t test

Pada teknik ini hasil yang ingin diperoleh yaitu apakah ada perbedaan persepsi dari responden berdasarkan jenis kelamin (Gender). Reponden akan diberikan dua pernyataan dan pilihan skala $1-7$, dimana skor 1 menyatakan sangat tidak setuju dan skor 7 sangat setuju. Persepsi yang akan diukur adalah sebagai berikut :

a Bank syariah memiliki sistem bagi hasil yang lebih menguntungkan bagi nasabah. (Persepsi A)

b. Bank syariah memiliki fasilitas ATM yang memadai. (Persepi B)

\subsection{Hasil Analisis Data}

Berikut merupakan hasil yang diperoleh dari data tersebut dengan menggunakan analisis pada aplikasi SPSS :

1. Teknik One Sample t test

Berdasarkan hasil perhitungan One sample $t$ test pada aplikasi SPSS dimana akurasi atau tingkat kepercayaan yang digunakan sebesar $95 \%$ dan alpha $(\alpha)$ sebesar $5 \%$, serta dugaan $(\mu)$ rata-rata uang yang ditabung setiap bulannya sebesar Rp 1.000.000,- . Maka diperoleh nilai mean sebesar 1.466.667, nilai tersebut menunjukan bahwa rata-rata uang yang ditabungkan setiap bulan dari lima belas responden baik mahasiswa maupun mahasiswi perguruan tinggi swasta di kota Bogor.

Hipotesis yang digunakan adalah sebagai berikut :

Ho : Rata-rata uang yang ditabung di bank syariah setiap bulan $=R p$ 1.000.000,-

$\mathrm{Ha}$ : Rata-rata uang yang ditabung di bank syariah setiap bulan $\neq \mathrm{Rp}$ 1.000.000,-

Dengan simpulan :

Terima Ho, Jika nilai Sig $>0,05$

Terima Ha, Jika nilai Sig $<0,05$

Berikut merupakan hasil bedasarkan perhitungan aplikasi SPSS, yang dapat dilihat pada Tabel 2. 
Tabel 2 Perhitungan SPSS One sample t test

One-Sample Test

Test Value $=1000000$

95\% Confidence Interval of

\begin{tabular}{|c|c|c|c|c|c|c|}
\hline & \multirow[b]{2}{*}{$\mathrm{t}$} & \multirow[b]{2}{*}{$d f$} & \multirow[b]{2}{*}{ Sig. (2-tailed) } & \multirow{2}{*}{$\begin{array}{c}\text { Mean } \\
\text { Difference }\end{array}$} & \multicolumn{2}{|c|}{ the Difference } \\
\hline & & & & & Lower & Upper \\
\hline $\begin{array}{l}\text { Uang_di } \\
\text { tabung }\end{array}$ & 4.525 & 14 & .000 & 466666.66667 & 245483.9275 & 687849.4058 \\
\hline
\end{tabular}

Berdasarkan perhitungan tersebut maka dapat ditarik kesimpulan bahwa rata-rata uang yang ditabung di bank setiap bulan tidak sama dengan Rp 1.000.000,- atau dengan kata lain terima $\mathrm{Ha}$ dan tolak Ho, karena nilai Sig $<0,05$ yaitu $0,000<0,05$.

2. Teknik Independent Sample t test

Berdasarkan hasil perhitungan Independent sample $t$ test pada aplikasi SPSS dimana akurasi atau tingkat kepercayaan yang digunakan sebesar $95 \%$ dan alpha $(\alpha)$ sebesar $5 \%$, serta dua pernyataan persepsi yang dipilh yaitu (Persepsi A) Bank syariah memiliki sistem bagi hasil yang lebih menguntungkan bagi nasabah, dan (Persepsi B) Bank syariah memiliki fasilitas ATM yang memadai. Maka diperoleh hasil sebagai berikut yang ditunjukan pada Tabel 3 .

Hipotesis yang digunakan sebagai berikut:

Ho :Tidak terdapat perbedaan persepsi antara mahasiswa dan mahasiswi.

$\mathrm{Ha}$ : Terdapat perebedaan persepsi anatara mahasiswa dan mahasiswi.

Dengan simpulan : Terima Ho, Jika nilai Sig $>0,05$

Terima Ha, Jika nilai Sig $<0,05$

Tabel 3 Perhitungan SPSS Independent sample t test

\begin{tabular}{|c|c|c|c|c|c|c|c|c|c|c|}
\hline \multicolumn{11}{|c|}{ Independent Samples Test } \\
\hline & & \multicolumn{2}{|c|}{$\begin{array}{l}\text { Levene's Test for Equality of } \\
\text { Variances }\end{array}$} & \multicolumn{7}{|c|}{ t-test for Equality of Means } \\
\hline & & \multirow[b]{2}{*}{$\mathrm{F}$} & \multirow[b]{2}{*}{ Sig. } & \multirow[b]{2}{*}{$t$} & \multirow[b]{2}{*}{ df } & \multirow[b]{2}{*}{ Sig. (2-tailed) } & \multirow{2}{*}{$\begin{array}{c}\text { Mean } \\
\text { Difference }\end{array}$} & \multirow{2}{*}{$\begin{array}{l}\text { Std. Error } \\
\text { Difference }\end{array}$} & \multicolumn{2}{|c|}{$\begin{array}{l}95 \% \text { Confidence Interval of the } \\
\text { Difference }\end{array}$} \\
\hline & & & & & & & & & Lower & Upper \\
\hline \multirow[t]{2}{*}{ Persepsi_A } & $\begin{array}{l}\text { Equal variances } \\
\text { assumed }\end{array}$ & .068 & .799 & 2.552 & 13 & .024 & .96429 & .37783 & .14802 & 1.78055 \\
\hline & $\begin{array}{l}\text { Equal variances not } \\
\text { assumed }\end{array}$ & & & 2.540 & 12.449 & .025 & .96429 & .37965 & .14040 & 1.78817 \\
\hline \multirow[t]{2}{*}{ Persepsi_B } & $\begin{array}{l}\text { Equal variances } \\
\text { assumed }\end{array}$ & .043 & .839 & .442 & 13 & .666 & .21429 & .48526 & -.83406 & 1.26263 \\
\hline & $\begin{array}{l}\text { Equal variances not } \\
\text { assumed }\end{array}$ & & & .441 & 12.631 & .667 & .21429 & .48620 & -.83922 & 1.26780 \\
\hline
\end{tabular}

Sumber : Data diolah dengan SPSS, 2018 
Berdasarkan perhitungan tersebut maka dapat ditarik kesimpulan bahwa hasil analisis kedua persepsi yang diujikan adalah sebagai berikut :

a. Persepsi $A$, dari hasil perhitungan dengan aplikasi SPSS ditunjukan bahwa nilai sig $>0,05$ yaitu 0,24 >0,05 atau dengan kata lain menerima Ho dan menolak Ha. Artinya tidak terdapat perbedaan persepsi antara mahasiswa dengan mahasiswi mengenai Bank syariah memiliki sistem bagi hasil yang lebih menguntungakan bagi nasabah.

b. Persepsi B, dari hasil perhitungan dengan aplikasi SPSS ditunjukan bahwa nilai sig $>0,05$ yaitu $0,67>0,05$ atau dengan kata lain menerima Ho dan menolak Ha. Artinya tidak terdapat perbedaan persepsi antara mahasiswa dengan mahasiswi mengenai Bank syariah memiliki fasilitas ATM yang memadai.

\section{Kesimpulan}

Berdasarkan hasil perhitungan dengan menggunakan aplikasi SPSS, dimana teknik analisis yang dilakukan yaitu dengan menggunakan teknik One sample $t$ test dan Independent sample $t$ test dengan jumlah responden lima belas orang yang memiliki status mahasiswa dan mahasiswi perguruan tinggi swasta di kota Bogor, maka diperoleh hasil sebagai berikut :

1. Hasil pengolahan data kuisioner dari jumlah lima belas responden menunjukan bahwa dengan menggunakan teknik One sample $t$ test diperoleh kesimpulan rata-rata uang yang ditabung di bank pada setiap bulan oleh mahasiswa maupun mahasiswi tidak sama dengan asumsi / dugaan yang sudah ditentukan sebelumnya yaitu sebesar Rp 1.000.000.

2. Hasil pengolahan data kuisioner dari jumlah lima belas responden yang terdiri dari delapan orang mahasiswi dan tujuh orang mahasiswa dengan membandingkan apakah terdapat perbedaan persepsi atau tidak berdasarkan gender menggunakan teknik Independent sample $t$ test, dan pengukuran persepsi dengan skala $1-7$ dimana skor 1 menyatakan sangat tidak setuju dan skor 7 menyatakan sangat setuju. Maka diperoleh kesimpulan sebagai berikut :

a. Pada persepsi A yang berbunyi "Bank syariah memiliki sistem bagi hasil yang lebih menguntungkan bagi nasabah" diperoleh hasil bahwa tidak terdapat perbedaan persepsi antara mahasiswa dengan mahasiswi mengenai Bank syariah memiliki sistem bagi hasil yang lebih menguntungakan bagi nasabah. Hal tersebut dibuktikan dengan nilai sig $>0,05$ yaitu $0,24>0,05$ sehingga hipotesis yang diterima yaitu $\mathrm{Ho}$, dan menolak Ha.

b. Pada persepsi B yang berbunyi "Bank syariah memiliki fasilitas ATM yang memadai" diperoleh hasil bahwa tidak terdapat perbedaan persepsi antara mahasiswa dengan mahasiswi mengenai Bank syariah memiliki fasilitas ATM yang memadai. Hal tersebut dibuktikan dengan nilai sig $>0,05$ yaitu $0,67>0,05$ sehingga hipotesis yang diterima yaitu Ho dan menolah $\mathrm{Ha}$. 


\section{Daftar Pustaka}

Arifin, Z. (2009). Dasar-dasar Manajemen Bank Syariah. Jakarta: Azkia Publisher

Kasmir. (2014). Bank dan Lembaga Keuangan Lainnya. Jakarta: Rajawali Perss

Setiawan, B. (2015). Teknik Praktis Analisis Data Penelitian Sosial \& Bisnis dengan SPSS. Yogyakarta: CV Andi Offset

Setiawan, B, Panduwangi, M, \& Sumintono, B.(2018). A Rasch analysis of the community's preference for different attributes of Islamic banks in Indonesia. International Journal of Social Economics. https://doi.org/10.1108/lJSE-07-2017-0294

Martono. (2002). http://www.definisi-pengertian.com/2015/07/definisipengertian-bank-konvensional-syariah. html. 